Volume 11 Nomor 1, November 2019, p. 097 - 113

Faculty of Law, Universitas Kristen Maranatha

ISSN: 2085-9945 I e-ISSN: 2579-3520

Nationally Accredited Journal by SINTA

\title{
PERBANDINGAN PENYELESAIAN SENGKETA MEREK BERDASARKAN UNDANG-UNDANG MEREK NOMOR 20 TAHUN 2016 TENTANG MEREK DAN INDIKASI GEOGRAFIS JO. UNDANG-UNDANG NOMOR 30 TAHUN 1999 TENTANG ARBITRASE DAN ALTERNATIF PENYELESAIAN SENGKETA DENGAN WORLD INTELLECTUAL PROPERTY ORGANIZATION ARBITRATION AND MEDIATION CENTRE
}

\author{
Shelly Kurniawan \\ Fakultas Hukum, Universitas Kristen Maranatha \\ shellyelviraa@gmail.com
}

Submitted: 2019-10-09| Reviewed: 2019-11-05| Accepted: 2019-11-11

\begin{abstract}
Dispute resolution does not only have to go through court, it can also resolve by alternative dispute resolution. Alternative dispute resolution regulated in Indonesia through Act Number 30 of 1999 concerning Arbitration and Alternative Dispute Resolution that more diverse than alternative dispute resolution provided by the World Intellectual Property Organization (WIPO) through the WIPO Arbitration and Mediation Centre (WIPO AMC). Alternative dispute resolution in Indonesia can be in consultation, mediation, negotiation, conciliation, arbitration, and expert determination. The WIPO AMC at least provides four option for the alternative dispute resolution, namely mediation, arbitration, expedited arbitration, and expert determination. This research is to compare the alternative dispute resolution in marks dispute resolution jo. The act of alternative dispute resolution and alternative dispute resolution on WIPO AMC. Through the WIPO AMC, it is expected that alternative dispute resolution in Indonesia can be more effective and efficient by implemented steps on WIPO $A M C$, by implementing an online system and diclosure of information about the estimated costs to be incurred by the parties. Only expedited arbitration that is not explicitly regulated in Act Number 30 of 1999 concerning Arbitration and Alternative Dispute Resolution, but there are provisions that resemble to expedited arbitration, i.e. a sole arbiter. Dispute resolution which is relatively very suitable to be used this day is using Online Dispute Resolution (ODR) system, so it will be more effective and efficient in time and cost if all the forms of dispute resolution mentioned above are accommodated by the ODR system. BANI have to provide the ODR system by website or application and make the regulations about the system.
\end{abstract}

Keywords: Alternative dispute resolution; comparation; trademarks. 
Dialogia luridica: Jurnal Hukum Bisnis dan Investasi

Vol. 11 (1): 097-113

\section{PENDAHULUAN}

Setiap orang yang berhubungan dengan orang lain memiliki kemungkinan untuk bersengketa dengan orang tersebut atau dengan pihak ketiga. Begitupun dengan pendaftaran kekayaan intelektual yang dapat menimbulkan sengketa dengan pihak Direktorat Jenderal Kekayaan Intelektual sebagai pihak yang memeriksa pendaftaran merek maupun dengan pihak ketiga yang merasa keberatan dengan didaftarkannya merek oleh pemohon merek. Sengketa yang terjadi dengan pihak Direktorat Jenderal Kekayaan Intelektual dapat disebabkan oleh ditolaknya atau tidak diterimanya pendaftaran merek pemohon karena memenuhi Pasal 20 dan/atau Pasal 21 Undang-Undang Nomor 20 Tahun 2016 tentang Merek dan Indikasi Geografis. Pemohon merek dapat bersengketa dengan pihak ketiga apabila pihak ketiga tersebut mengajukan keberatan atas pendaftaran merek pemohon karena merek tersebut dirasa memiliki kesamaan dengan merek yang telah ada dan/atau merek tersebut didaftarkan atas itikad tidak baik.

Penyelesaian sengketa untuk merek dilakukan di Pengadilan Niaga. Undang-Undang Nomor 20 Tahun 2016 tentang Merek dan Indikasi Geografis mengatur pula bahwa penyelesaian sengketa dapat dilakukan dengan alternatif penyelesaian sengketa selain diselesaikan melalui Pengadilan Niaga. Tata cara gugatan pada Pengadilan Niaga diatur dalam Bagian Kedua Undang-Undang Nomor 20 Tahun 2016 tentang Merek dan Indikasi Geografis. Pasal 93 Undang-Undang Nomor 20 Tahun 2016 tentang Merek dan Indikasi Geografis menyebutkan bahwa penyelesaian sengketa atas adanya gugatan dapat dilakukan melalui arbitrase dan alternatif penyelesaian sengketa. Penjelasan Pasal 93 Undang-Undang Nomor 20 Tahun 2016 tentang Merek dan Indikasi Geografis dapat dilakukan melalui negosiasi, mediasi, konsiliasi, dan cara lain yang dipilih oleh para pihak. Penyelesaian sengketa yang diatur dalam pasal tersebut sesuai dengan yang diatur dalam Undang-Undang Nomor 30 Tahun 1999 tentang Arbitrase dan Alternatif penyelesaian sengketa. Alternatif penyelesaian sengketa menurut Pasal 1 angka 10 Undang-Undang Nomor 30 Tahun 1999 tentang Arbitase dan Alternatif Penyelesaian Sengketa menyebutkan pula penyelesaian sengketa dapat dilakukan dengan cara konsultasi dan penilaian ahli selain dengan cara-cara yang disebutkan dalam Pasal 93 Undang-Undang Nomor 20 Tahun 2016 tentang Merek dan Indikasi Geografis. 
World Intellectual Property Organization (WIPO) sebagai forum global untuk layanan, kebijakan, informasi, dan kerjasama di bidang kekyaan intelektual. ${ }^{1}$ WIPO mengatur bahwa sengketa yang terjadi mengenai kekayaan intelektual diselesaikan dengan cara alternatif penyelesaian sengketa. Hal tersebut direkomendasikan sebagai sarana untuk menyelesaikan sengketa karena jangka waktu yang dibutuhkan untuk menyelesaikan sengketa lebih singkat dibandingkan dengan penyelesaian sengketa di pengadilan. Selain itu biaya yang dikeluarkan relatif lebih murah dibandingkan dengan perkara yang masuk ke pengadilan, penyelesaian sengketa dilakukan oleh pihak yang berkompeten dan netral, serta reputasi bisnis perusahaan akan lebih terjaga karena prinsipnya sangat rahasia (confidential). ${ }^{2}$ Penelitian ini untuk membandingkan bentuk penyelesaian sengketa yang sudah ada di Indonesia melalui UndangUndang Nomor 30 Tahun 1999 tentang Arbitrase dan Alternatif Penyelesaian Sengketa dengan penyelesaian sengketa yang disediakan oleh WIPO Arbitration and Mediation Centre (WIPO AMC). Melalui mekanisme dalam WIPO AMC, diharapkan alternatif penyelesaian sengketa di Indonesia dapat lebih efektif dan efisien dengan cara atau langkah yang diterapkan oleh WIPO AMC, yaitu dengan diterapkannya sistem online dan keterbukaan informasi mengenai estimasi biaya yang akan dikeluarkan para pihak nantinya.

Sengketa mengenai merek pun seyogyanya dapat diselesaikan dengan cepat, yaitu dengan menggunakan alternatif penyelesaian sengketa. Alternatif penyelesaian sengketa di era ini sudah dapat menggunakan sistem internet, misalnya dengan sistem Online Dispute Resolution (ODR). Sistem penyelesaian sengketa secara online ini diharapkan dapat memenuhi kebutuhan masyarakat untuk mendapatkan keadilan, kemanfaatan, dan kepastian hukum dari sengketa yang dihadapinya, termasuk mengenai sengketa merek yang sangat berkaitan dengan dunia bisnis. Diharapkan juga Indonesia melalui Badan Arbitrase Nasional Indonesia (BANI) mulai membuat sistem ODR dalam bentuk website atau aplikasi dan regulasi dari ODR ini dapat dirumuskan dalam perubahan Undang-Undang Nomor 30 Tahun 1999 tentang Arbitrase dan Alternatif Penyelesaian Sengketa.

\section{PEMBAHASAN}

Alternatif Penyelesaian Sengketa menurut Pasal 1 angka 10 Undang-Undang Nomor 30 Tahun 1999 tentang Arbitrase dan Alternatif Penyelesaian Sengketa adalah lembaga

\footnotetext{
${ }^{1}$ Dheka Ermelia Putri, Penerapan Online Dispute Resolution (ODR) Dalam Penyelesaian Sengketa Nama Domain Internasional, Fakultas Hukum Universitas Lampung, 2018, hlm 44.

${ }^{2}$ Claus Matthes, Recent Developments in WIPO Administered IP Services, Munich: World Intellectual Property Organization (WIPO), 2016, hlm 87.
} 
Dialogia luridica: Jurnal Hukum Bisnis dan Investasi

Vol. 11 (1): 097-113

penyelesaian sengketa atau beda pendapat melalui prosedur yang disepakati para pihak, yakni penyelesaian di luar pengadilan dengan cara konsultasi, negosiasi, mediasi, konsiliasi, atau penilaian ahli. Pengertian tersebut sekaligus menyebutkan jenis-jenis dari alternatif penyelesaian sengketa yang dapat dilakukan di Indonesia. Menurut WIPO, terdapat 4 (empat) pilihan alternatif penyelesaian sengketa, yaitu:

1. Mediation: informal consensual process in which a neutral intermediary, the mediator, assist the parties in reaching a settlement of their dispute, based on the parties' respective interest. The mediator cannot impose a decision. The settlement agreement has force of contract. Mediation leaves open available court or agreed arbitration option.

2. Arbitration: consensual procedure in which the parties submit their dispute to one or more chosen arbitrators, for a binding and final decision (award) based on the parties' rights and enforceable internationally. Arbitration normally forecloses court options.

3. Expert determination: consensual procedure in which the parties submit a specific matter (e.g., technical question) to one or more experts who make a determination on the matter, which can be binding unless the parties have agreed otherwise. ${ }^{3}$

4. Expedited arbitration: a procedure that normally involves a sole arbitrator and which is carried out in short time frame and at reduce cost. Expedited arbitration is especially suited to less complex cases involving lower disputed amounts and where speedy resolution is needed. ${ }^{4}$

Berdasarkan jenis alternatif penyelesaian sengketa di atas, terdapat 3 (tiga) jenis alternatif penyelesaian sengketa, yaitu mediasi, arbitrase, dan penilaian ahli. Penyelesaian sengketa melalui arbitrase dapat dipilih berdasarkan kebutuhan, yaitu arbitrase biasa dan arbitrase yang diperuntukan untuk kasus yang tidak begitu rumit, dana yang dipersengketakan tidak terlalu besar, dan dibutuhkan waktu yang lebih cepat untuk penyelesaiannya. Berikut adalah tabel perbandingan penyelesaian sengketa antara yang diatur dalam Pasal 93 Undang-Undang Nomor 20 Tahun 2016 tentang Merek dan Indikasi Geografis jo. Pasal 1 angka 10 UndangUndang Nomor 30 Tahun 1999 tentang Arbitrase dan Alternatif Penyelesaian Sengketa dengan penyelesaian sengketa yang diatur dalam WIPO:

\footnotetext{
3 ibid, hlm 87.

${ }^{4}$ https://www.wipo.int/wipo_magazine/en/2016/si/article_0010.html, diakses pada tanggal 14 Agustus 2019 pkl 10.53 WIB.
} 


\begin{tabular}{|c|c|c|c|c|}
\hline No. & $\begin{array}{c}\text { Alternatif } \\
\text { Penyelesaian } \\
\text { Sengketa }\end{array}$ & $\begin{array}{c}\text { Pasal } 93 \text { Undang- } \\
\text { Undang Nomor } 20 \\
\text { Tahun } 2016 \text { tentang } \\
\text { Merek dan Indikasi } \\
\text { Geografis jo. Pasal } 1 \\
\text { angka } 10 \text { Undang- } \\
\text { Undang Nomor } 30 \\
\text { Tahun } 1999 \text { tentang } \\
\text { Arbitrase dan } \\
\text { Alternatif } \\
\text { Penyelesaian Sengketa }\end{array}$ & WIPO AMC & Pengertian \\
\hline 1 & Konsultasi & $\begin{array}{lr}\text { Tidak } & \text { terdapat } \\
\text { penjelasan } & \text { mengenai } \\
\text { konsultasi } & \end{array}$ & $\begin{array}{l}\text { Tidak terdapat } \\
\text { penjelasan } \\
\text { mengenai } \\
\text { konsultasi }\end{array}$ & $\begin{array}{l}\text { Konsultasi } \\
\text { merupakan suatu } \\
\text { tindakan yang } \\
\text { besifat personal } \\
\text { antara satu pihak } \\
\text { tertentu (klien) } \\
\text { dengan pihak lain } \\
\text { (konsultan) } \\
\text { dimana konsultan } \\
\text { memberikan } \\
\text { pendapatnya } \\
\text { kepada klien } \\
\text { tersebut untuk } \\
\text { memenuhi } \\
\text { keperluan dan } \\
\text { kebutuhan klien } \\
\text { tersebut, namun } \\
\text { klien diberi } \\
\text { kebebasan untuk } \\
\text { melaksanakan } \\
\text { atau tidak } \\
\text { melaksanakan } \\
\text { pendapat } \\
\text { konsultan } \\
\text { tersebut. }\end{array}$ \\
\hline 2 & Negosiasi & $\begin{array}{l}\text { Tidak ada penjelasan } \\
\text { mengenai negosiasi }\end{array}$ & $\begin{array}{l}\text { Tidak mengatur } \\
\text { mengenai negosiasi }\end{array}$ & $\begin{array}{l}\text { Negosiasi adalah } \\
\text { cara penyelesaian } \\
\text { sengketa di luar }\end{array}$ \\
\hline
\end{tabular}

5 Nevey Varida Ariani, “Alternatif Penyelesaian Sengketa Bisnis di Luar Pengadilan”, Jurnal Rechtsvinding, Vol. 1 No. 2, 2012, hlm 281. 


\begin{tabular}{|c|c|c|c|c|}
\hline & & & & $\begin{array}{l}\text { pengadilan yang } \\
\text { dilakukan oleh } \\
\text { pihak-pihak yang } \\
\text { bersengketa atau } \\
\text { kuasanya secara } \\
\text { langsung, tanpa } \\
\text { keterlibatan } \\
\text { pihak ketiga } \\
\text { sebagai } \\
\text { penengah. }\end{array}$ \\
\hline 3 & Mediasi & $\begin{array}{l}\text { Tidak ada penjelasan } \\
\text { mengenai mediasi. }\end{array}$ & $\begin{array}{l}\text { Mediasi adalah } \\
\text { proses kesepakatan } \\
\text { di bawah tangan } \\
\text { yang terdapat pihak } \\
\text { yang menengahi, } \\
\text { yaitu mediator, } \\
\text { untuk membantu } \\
\text { para pihak } \\
\text { mendapatkan solusi } \\
\text { atas sengketa } \\
\text { mereka dapat } \\
\text { berdasarkan } \\
\text { kepentingan para } \\
\text { pihak. Mediator } \\
\text { tidak memberikan } \\
\text { metusan. Perjanjian } \\
\text { perdamaian } \\
\text { memiliki kekuatan } \\
\text { mengikat. Mediasi } \\
\text { membuka } \\
\text { kesempatan untuk } \\
\text { ke pengadilan atau } \\
\text { arbitrase. }\end{array}$ & $\begin{array}{lr}\text { Mediasi } & \text { dalam } \\
\text { Pasal 1 angka } 1 \\
\text { Perma Nomor } 1 \\
\text { Tahun } 2016 \\
\text { tentang Prosedur } \\
\text { Mediasi di } \\
\text { Pengadilan } \\
\text { adalah } \\
\text { penyelesaian } \\
\text { sengketa melalui } \\
\text { proses } \\
\text { perundingan } \\
\text { untuk } \\
\text { memperoleh } \\
\text { kesepakatan para } \\
\text { pihak dengan } \\
\text { dibantu oleh } \\
\text { mediator. }\end{array}$ \\
\hline 4 & Konsiliasi & $\begin{array}{l}\text { Tidak ada penjelasan } \\
\text { mengenai konsiliasi }\end{array}$ & $\begin{array}{ll}\text { Tidak } & \text { diatur } \\
\text { mengenai } & \\
\text { konsiliasi } & \end{array}$ & $\begin{array}{l}\text { Konsiliasi adalah } \\
\text { penyelesaian } \\
\text { sengketa } \\
\text { alternatif yang } \\
\text { juga melibatkan }\end{array}$ \\
\hline
\end{tabular}

6 Rahmi Yuniarti, "Efisiensi Pemilihan Alternatif Penyelesaian Sengketa Dalam Penyelesaian Sengketa Waralaba", Fiat Justitia Journal of Law, Vol. 10, Issue 3, 2016, hlm. 563.
$7 \quad$ Terjemahan
bebas
penulis
dari
pengertian
mediation,
op.cit, https://www.wipo.int/wipo_magazine/en/2016/si/article_0010.html 


\begin{tabular}{|c|c|c|c|c|}
\hline & & & & $\begin{array}{l}\text { pihak ketiga, baik } \\
\text { sendiri maupun } \\
\text { beberapa orang. } \\
\text { Konsiliator } \\
\text { biasanya } \\
\text { seoarang yang } \\
\text { diakui } \\
\text { kompetensi dan } \\
\text { pengalamannya } \\
\text { yang secara } \\
\text { professional telah } \\
\text { diakui } \\
\text { kemampuannya } \\
\text { sebagai } \\
\text { penengah. }\end{array}$ \\
\hline 5 & Arbitrase & $\begin{array}{l}\text { Arbitrase adalah cara } \\
\text { penyelesaian suatu } \\
\text { sengketa perdata di luar } \\
\text { peradilan umum yang } \\
\text { didasarkan pada } \\
\text { perjanjian arbitrase } \\
\text { yang dibuat secara } \\
\text { tertulis oleh para pihak } \\
\text { yang bersengketa (Pasal } \\
1 \text { angka 1 Undang- } \\
\text { Undang Nomor } 30 \\
\text { Tahun 1999 tentang } \\
\text { Arbitase dan Alternatif } \\
\text { Penyelesaian Sengketa). }\end{array}$ & $\begin{array}{l}\text { Arbitrase adalah } \\
\text { prosedur } \\
\text { kesepakatan } \\
\text { dimana para pihak } \\
\text { mengajukan } \\
\text { sengketa di antara } \\
\text { mereka kepada satu } \\
\text { atau lebih arbiter } \\
\text { yang dipilih untuk } \\
\text { membuat } \\
\text { keputusan yang } \\
\text { final dan mengikat } \\
\text { (putusan) } \\
\text { berdasarkan hak- } \\
\text { hak para pihak dan } \\
\text { dapat dilaksanakan } \\
\text { secara } \\
\text { internasional. } \\
\text { Biasanya arbitase } \\
\text { menutup opsi } \\
\text { pengadilan. }{ }^{9}\end{array}$ & $\begin{array}{l}\text { Putusan arbitrase } \\
\text { tidak dapat } \\
\text { diajukan } \\
\text { banding, yang } \\
\text { dapat menjadi } \\
\text { kelebihan } \\
\text { sekaligus } \\
\text { kekurangan } \\
\text { arbitrase, dan } \\
\text { berkaitan dengan } \\
\text { pengakutan dan } \\
\text { pelaksanaan } \\
\text { keputusan } \\
\text { arbitrase asing } \\
\text { atau internasional } \\
\text { di negara pihak } \\
\text { yang kalah } \\
\text { seringkali } \\
\text { menimbulkan } \\
\text { kesulitan. }{ }^{10}\end{array}$ \\
\hline 6 & $\begin{array}{l}\text { Expedited } \\
\text { Arbitration }\end{array}$ & $\begin{array}{l}\text { Tidak diatur mengenai } \\
\text { expedited arbitration. }\end{array}$ & $\begin{array}{l}\text { Expedited } \\
\text { arbitration adalah }\end{array}$ & $\begin{array}{l}\text { Undang-Undang } \\
\text { Nomor } 30 \text { Tahun }\end{array}$ \\
\hline
\end{tabular}

\footnotetext{
${ }^{8}$ Marwah M. Diah, "Prinsip dan Bentuk-Bentuk Alternatif Penyelesaian Sengketa di Luar Pengadilan", Hukum dan Dinamika Masyarakat, Vol. 5, No. 2, 2008, hlm. 118.

9 Terjemahan bebas penulis dari pengertian arbitration, op.cit, https://www.wipo.int/wipo_magazine/en/2016/si/article_0010.html

${ }^{10}$ Madjedi Hasan, "Hal-Hal yang Perlu Dipertimbangkan Sebelum Menandatangani Kesepakatan Berarbitrase, Indonesian Arbitration”, Quarterly Newsletter, No. 11, 2010, hlm 26.
} 


\begin{tabular}{|c|c|c|c|c|}
\hline & & & 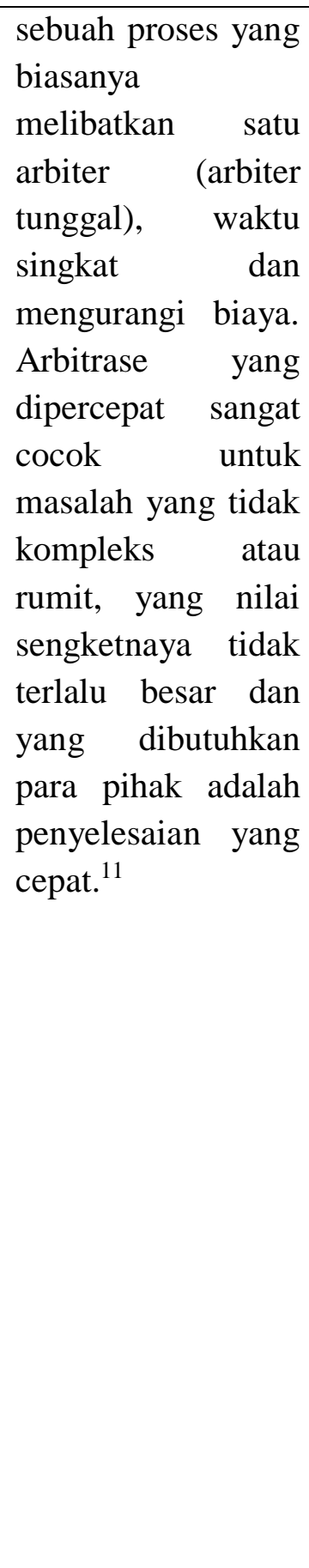 & 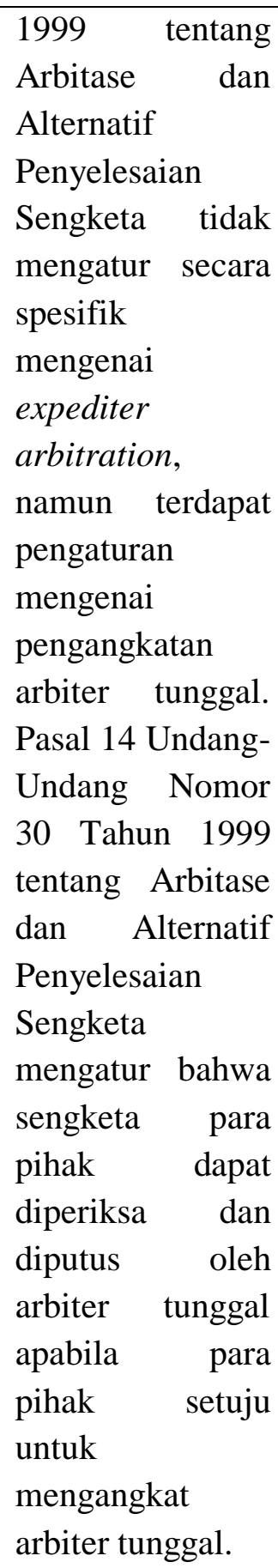 \\
\hline 7 & Penilaian ahli & $\begin{array}{l}\text { Tidak terdapat } \\
\text { penjelasan mengenai } \\
\text { penilaian ahli. }\end{array}$ & $\begin{array}{l}\text { Prosedur } \\
\text { kesepakatan } \\
\text { dimana para pihak } \\
\text { mengajukan } \\
\text { sengketa yang } \\
\text { spesifik (seperti } \\
\text { pertanyaan teknis) } \\
\text { kepada satu atau }\end{array}$ & \begin{tabular}{lr} 
Penilaian ahli \\
merupakan \\
\multicolumn{2}{l}{ penyelesaian } \\
sengketa oleh \\
seorang atau \\
lebih ahli yang \\
menguasai & \\
bidang & yang
\end{tabular} \\
\hline
\end{tabular}

11 Terjemahan bebas penulis dari pengertian expedited arbitration, op.cit, https://www.wipo.int/wipo_magazine/en/2016/si/article_0010.html. 


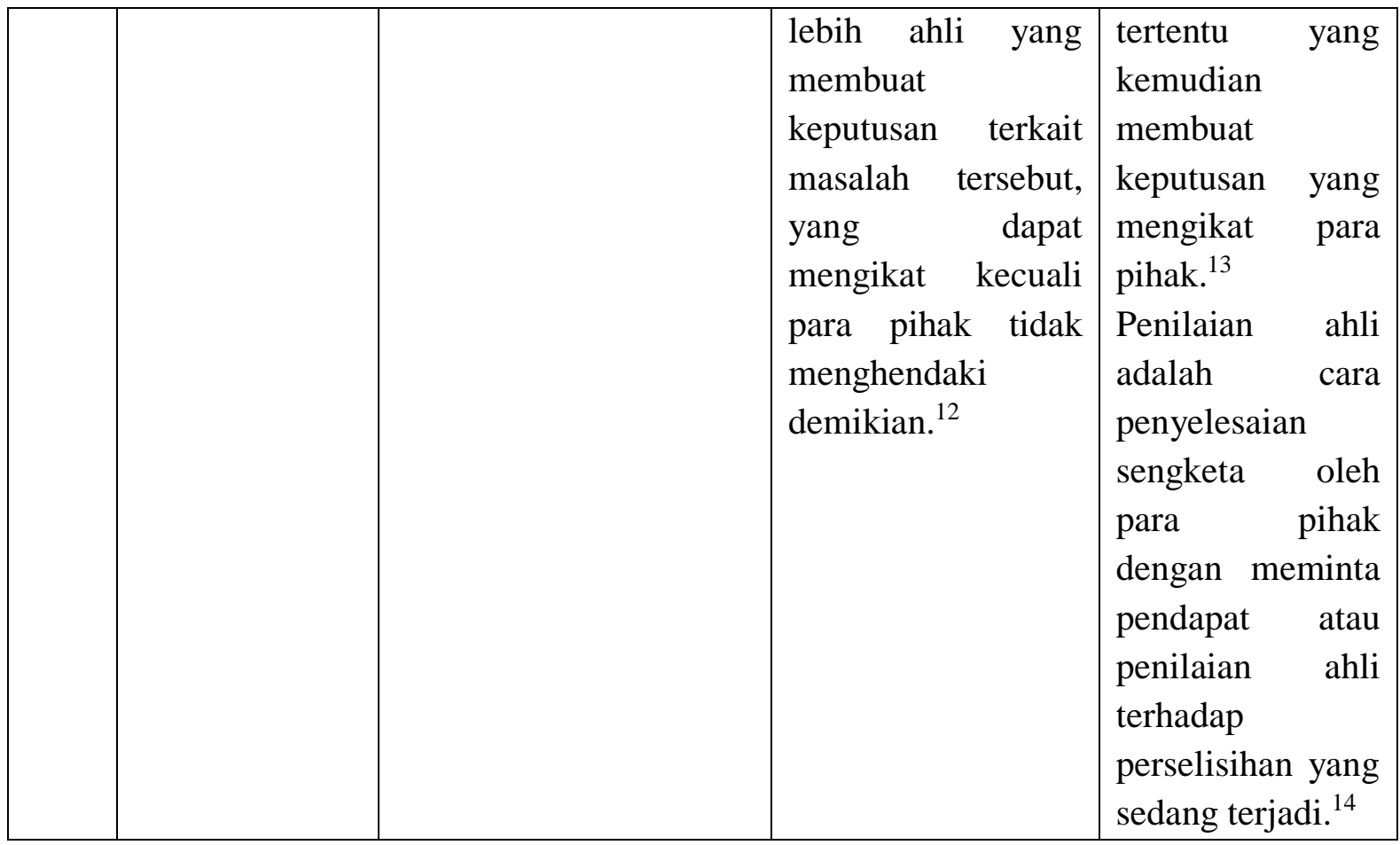

Secara garis besar, Undang-Undang Nomor 30 Tahun 1999 tentang Arbitrase dan Alternatif Penyelesaian Sengketa tidak mengatur semua definisi mengenai setiap jenis alternatif penyelesaian sengketa, sehingga pengertian dari setiap jenis tersebut dapat ditemukan dari doktrin atau pendapat para ahli. Undang-Undang Nomor 30 Tahun 1999 tentang Arbitrase dan Alternatif Penyelesaian Sengketa mengatur mengenai proses atau tata cara melaksanakan mediasi dan arbitrase, namun undang-undang tersebut lebih fokus atau rinci mengatur mengenai proses atau alur melaksanakan arbitase. Penyelesaian sengketa kekayaan intelektual melalui arbitrase dan mediasi dapat diajukan melalui Badan Arbitrase dan Mediasi Kekayaan Intelektual (BAM KI) yang memiliki keuntungan, seperti tertutup untuk umum, penyelesaiannya dibatasi selama 180 (seratus delapan puluh) hari, prosedurnya sederhana, biaya relatif lebih murah, dan putusan majelis arbiter bersifat final dan mengikat para pihak yang bersengketa. ${ }^{15}$ Penyelesaian sengketa yang diatur dalam Pasal 93 UndangUndang Nomor 20 Tahun 2016 tentang Merek dan Indikasi Geografis merujuk pada Undang-

12 Terjemahan bebas penulis dari pengertian expert determination, op.cit, https://www.wipo.int/wipo magazine/en/2016/si/article 0010.html

${ }^{13}$ https://bppk.kemenkeu.go.id/id/publikasi/artikel/147-artikel-anggaran-dan-perbendaharaan/9925-penyelesaiansengketa-dalam-pengadaan-barangjasa-pemerintah-melalui-alternative-dispute-resolution, diakses pada tanggal 20 Agustus 2019, pukul 17.00 WIB.

${ }^{14}$ Takdir Rahmadi, Mediasi Penyelesaian Sengketa Melalui Pendekatan Mufakat, Jakarta: Rajawali Pers, 2011, hlm 19

${ }^{15}$ Sedjana, "Efektivitas dan Efisiensi Penyelesaian Sengketa Kekayaan Intelektual Melalui Arbitase dan Mediasi Berdasarkan Undang-Undang Nomor 30 Tahun 1999”, AJUDIKASI: Jurnal Ilmu Hukum, Vol. 2, No. 1, 2018 , hlm 86. 
Dialogia luridica: Jurnal Hukum Bisnis dan Investasi

Vol. 11 (1): 097-113

Undang Nomor 30 Tahun 1999 tentang Arbitase dan Alternatif Penyelesaian Sengketa, yang terdiri dari konsultasi, negosiasi, mediasi, konsiliasi, arbitrase, dan penilaian ahli.

Konsultasi. Konsultasi pada umumnya sering digunakan oleh banyak pihak karena cara ini adalah sarana yang paling simple. Sifat dari hasil konsultasi tidak memaka sehingga pihak yang meminta pendapat tidak diwajibkan untuk melaksanakan hasil konsultasi dengan konsultan. Konsultasi adalah cara penyelesaian sengketa yang paling mudah dan dapat digunakan di kehidupan sehari-hari.

Negosiasi. Negosiasi dapat dikategorikan cara penyelesaian sengketa yang juga simple, namun sulit untuk menemukan solusi apabila kedua belah pihak bersikukuh dengan keinginan atau kepentingan masing-masing. Seringkali para pihak yang bersengketa enggan untuk bertemu satu sama lain karena dapat memperparah keadaan dengan adanya kepentingan yang sama kuatnya antara satu dengan yang lain. Cara penyelesaian ini dapat sangat cepat terwujud apabila minimal salah satu pihak dapat mengalah dan setuju dengan solusi yang dibuat saat negosiasi karena yang berkaitan langsung adalah para pihak yang bersengketa.

Mediasi. Pengertian yang disebutkan dalam Perma Nomor 1 Tahun 2016 tentang Prosedur Mediasi di Pengadilan dan WIPO AMC mengenai mediasi pada prinsipnya adalah sama. Mediasi dalam kedua pengertian tersebut mengandung unsur:

1. Proses penyelesaian sengketa yang berdasarkan perundingan;

2. Mediator terlibat dan diterima oleh para pihak yang bersengketa di dalam perundingan;

3. Mediator bertugas membantu para pihak yang bersengketa untuk mencari penyelesaian;

4. Mediator tidak mempunyai kewenangan membuat keputusan selama perundingan berlangsung;

5. Tujuan mediasi adalah untuk mencapai atau menghasilkan kesepakatan yang dapat diterima pihak-pihak yang bersengketa guna mengakhiri sengketa. ${ }^{16}$

Konsiliasi. Konsiliasi memiliki kesamaan dengan mediasi, yaitu adanya pihak ketiga yang menengahi para pihak yang bersengketa, namun konsiliator sebagai pihak ketiga dapat lebih aktif dalam proses konsiliasi. Pasal 7 Undang-Undang Nomor 30 Tahun 1999 tentang

\footnotetext{
${ }^{16}$ Suyud Margono, Penyelesaian Sengketa Bisnis Alternative Dispute Resolution (ADR), Bogor: Ghalia Indonesia, 2010, hlm 54-55.
} 
Arbitase dan Alternatif Penyelesaian Sengketa menyebutkan bahwa para pihak dapat menyelesaikan sengketa yang sudah terjadi atau yang mungkin akan terjadi melalui arbitrase. Pasal 9 Undang-Undang Nomor 30 Tahun 1999 tentang Arbitase dan Alternatif Penyelesaian Sengketa mengatur bahwa para pihak yang memilih penyelesaian sengketa melalui arbitrase setelah sengketa terjadi, harus dibuat dalam suatu perjanjian tertulis yang ditandatangani para pihak atau dibuat dalam akta notaris apabila para pihak tidak dapat menandatangani perjanjian tertulis tersebut. WIPO AMC pun mengatur bahwa penyelesaian sengketa melalui mediasi, penilaian ahli, arbitrase, dan arbitrase yang dipercepat harus sudah ditentukan dalam kontrak bahwa para pihak hendak untuk menyelesaikan sengketa yang terjadi melalui cara yang disediakan oleh WIPO AMC (terdapat klausula untuk menyelesaikan sengketa melalui alternatif penyelesaian apa, kesepakatan lokasi untuk menyelesaikan sengketa, Bahasa yang akan digunakan, dan hukum yang akan digunakan). ${ }^{17}$

Arbitrase yang dipercepat dengan arbitrase tunggal memiliki keterkaitan, namun karena Undang-Undang Nomor 30 Tahun 1999 tentang Arbitase dan Alternatif Penyelesaian Sengketa tidak mengatur lebih rinci mengenai hal tersebut, arbiter yang terdapat pada arbitrase tunggal menjadi salah satu syarat diadakannya arbitrase yang dipercepat. Tujuan diadakannya arbitrase yang dipercepat adalah agar sengketa dapat selesai lebih cepat dan biaya yang dikeluarkan lebih sedikit disbanding arbitrase yang melibatkan 3 (tiga) arbiter.

Penilaian Ahli. Penilaian ahli merupakan bentuk penilaian ahli yang dapat dipahami dan diterima oleh para pihak yang bersengketa. ${ }^{18}$ Hasil dari penilaian ahli berupa keterangan tertulis yang merupakan hasil telaahan ilmiah berdasarkan keahlian yang dimiliki untuk membuat terang pokok perkara. Penilaian ahli ini dapat diperoleh dari seseorang atau tim ahli yang dipilih secara ad hoc. Penilaian ahli dapat mengikat dan bisa juga tidak mengikat, tergantung pada kesepakatan para pihak maupun aturan yang berlaku. ${ }^{19}$

Penyelesaian sengketa menggunakan WIPO AMC lebih terbuka dari segi biaya karena terdapat kalkulator yang dapat menunjukkan perkiraan biaya yang harus dikeluarkan untuk pihak-pihak yang hendak menggunakan alternatif penyelesaian sengketa, yaitu terhubung dengan SCC. ${ }^{20}$ SCC (Small Claim Court) adalah mekanisme penyelesaian sengketa secara

\footnotetext{
${ }^{17}$ Matthew Bryan, "Resolving IP Disputes outside the Courts through WIPO ADR: WIPO's Arbitration and Mediation Center", Roving Seminar on WIPO Services and Initiatives, 2015, hlm 163.

${ }^{18}$ Idris Talib, "Bentuk Putusan Penyelesaian Sengketa Berdasarkan Mediasi”, Lex et Societatis, Vol.I, No.1, 2013, hlm 23 .

${ }^{19}$ Guidelines Mediasi untuk Direktorat Jenderal Hak Kekayaan Intelektual Kementerian Hukum dan HAM RI, hlm 8 .

${ }^{20}$ Arbitration Institute of the Stockholm Chamber of Commerce, diakses melalui https://sccinstitute.com/ourservices/calculator/ pada tanggal 25 Agustus 2019 pukul 20.00 WIB.
} 
cepat, sederhana, dan murah, tapi memberikan kekuatan hukum. SCC telah diimplementasikan pemerintah Indonesia dalam peraturan perundang-undangan di bidang kekayaan intelektual, salah satunya merek, namun karena batas waktu yang singkat dan lokasi Pengadilan Niaga hanya di 5 (lima) lokasi di Indonesia (Jakarta Pusat, Medan, Semarang, Surabaya, dan Ujung Pandang), penyelesaian sengketa melalui SCC malah menjadi mahal dan lama. ${ }^{21}$

Melalui sistem SCC yang disediakan WIPO, para pihak dapat memasukkan besarnya nominal yang disengketakan dan memilih jumlah pihak pengengah untuk arbiter. Hasil dari kalkulator tersebut dapat keluar perkiraan biaya untuk tingkatan pihak penengah (minimum, median, dan maximum), biaya untuk mediator atau arbiter (beserta dua arbiter lainnya) berdasarkan tingkatan, biaya administratif, dan perkiraan biaya lainnya. ${ }^{22}$ Sistem seperti yang diterapkan oleh WIPO tersebut sangat baik apabila dapat diterapkan di Indonesia agar lebih terbuka dari segi biaya. Penggunaan sistem SCC ini pun dapat dikatakan sebagai awal untuk menerapkan sistem ODR. ODR merupakan salah satu alternatif penyelesaian sengketa dengan menggunakan media elektronik dan jaringan internet dalam proses penyelesaiannya sehingga para pihak tidak perlu bertatap muka secara fisik. ${ }^{23}$ Pada dasarnya sistem arbitrase dan alternatif penyelesaian sengketa secara online tidak jauh berbeda dari arbitrase dan penyelesaian sengketa secara tradisional. Perbedaaannya hanyalah mengenai cara yang digunakan, yaitu penggunaan sarana-sarana elektronik dalam penyelenggaraannya, yaitu dalam hal pendaftaran perkara, pemilihan arbiter, penyerahan dokumen, dan pembuatan putusan dilakukan secara online. ${ }^{24}$ Arbitrase online dilakukan di internet atau dunia maya dan proses penyelesaian sengketanya pada umumnya tidak dilakukan melalui tatap muka secara lansung (tapi dapat juga mempertemukan kedua belah pihak apabila dibutuhkan demi kelancaran proses penyelesaian sengketa), sedangkan penyelesaian secara konvensional harus mempertemukan para pihak secara langsung. ${ }^{25}$

\footnotetext{
${ }^{21}$ Henry Donald Lbn Toruan, "Penyelesaian Sengketa Intelektual Melalui Acara Cepat", Jurnal Penelitian Hukum De Jure, Vol. 17, No. 1, 2017, hlm 76 dan 89.

${ }^{22}$ Arbitration Institute of the Stockholm Chamber of Commerce, op.cit.

${ }^{23}$ Hudiyanto, et.al., Tinjauan Umum Alternatif Penyelesaian Sengketa di Sektor Jasa Keuangan dan Online Dispute Resolution (ODR), Jakarta: Departemen Perlindungan Konsumen - Otoritas Jasa Keuangan, 2017, hlm 27.

${ }^{24}$ Abdul Halim Barkatullah, "Penerapan Arbitrase Online Dalam Penyelesaian Sengketa Transaksi ECommerce", Jurnal Hukum, Vol. 17, No. 3, 2010, hlm 369.

${ }_{25}$ Bambang Sutiyoso, "Penyelesaian Sengketa Bisnis Melalui Online Dispute Resolution dan Pemberlakukannya di Indonesia”, Mimbar Hukum, Vol. 20, No. 2, 2008, hlm 233.
} 
Dialogia luridica: Jurnal Hukum Bisnis dan Investasi

Vol. 11 (1): 097-113

Gambaran dari penerapan sistem SCC sebagai bentuk awal ODR tersebut adalah sebagai berikut: ${ }^{26}$

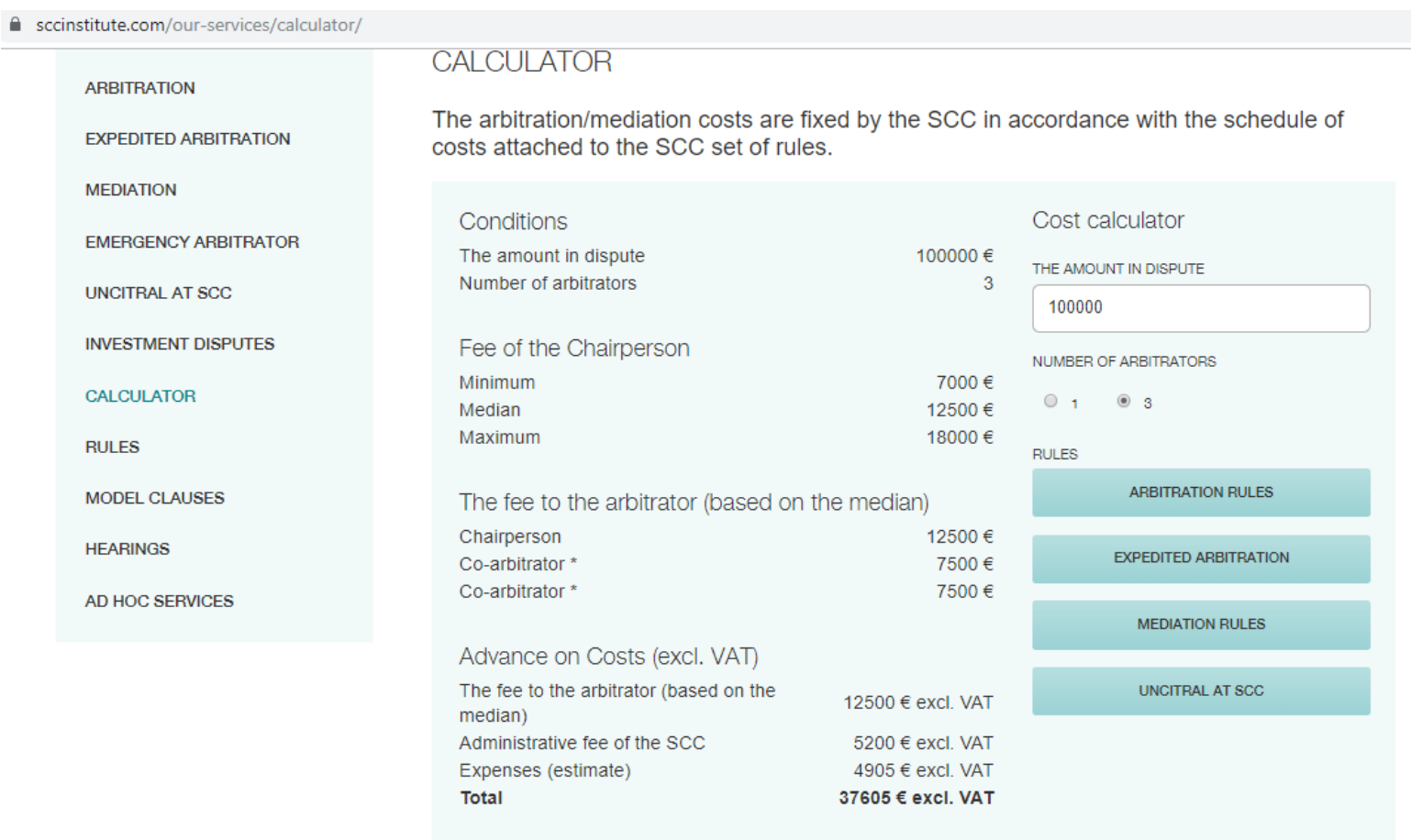

aipo.int/amc/en/calculator/adr.jsp

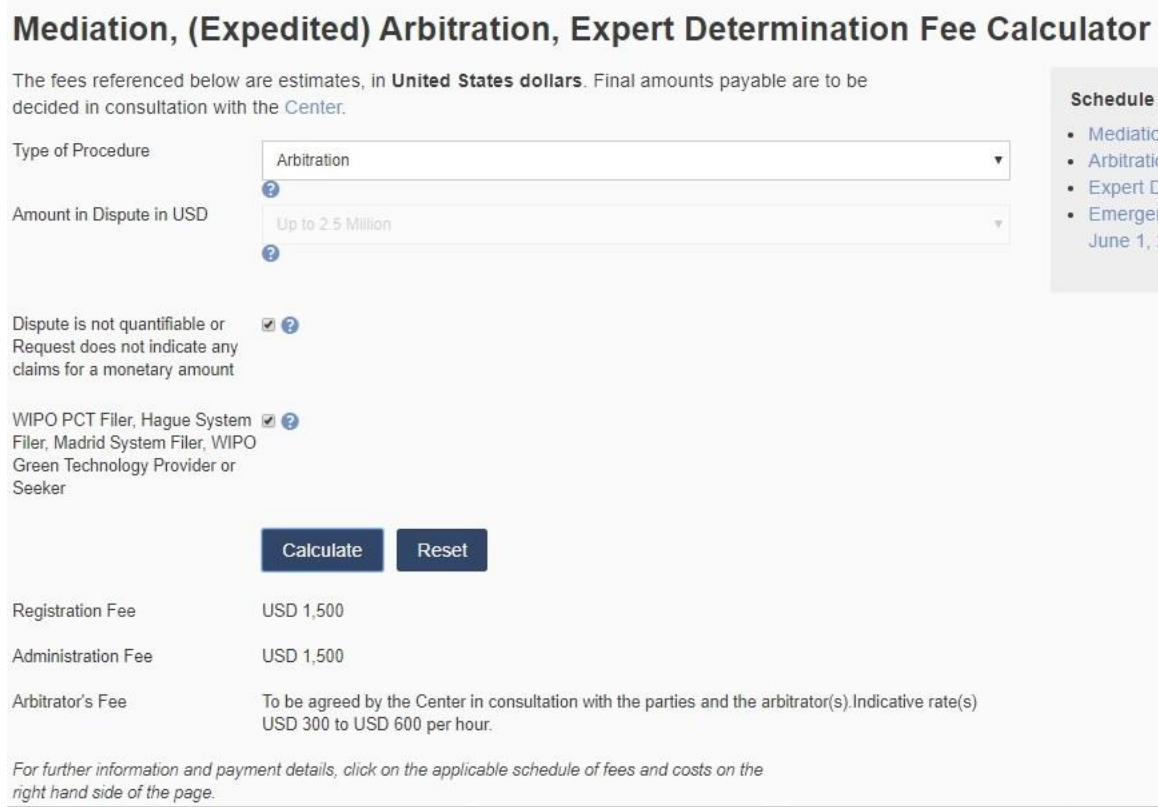

Indonesia belum memiliki sistem ODR yang dapat digunakan oleh para pihak untuk menyelesaikan sengketa yang relatif lebih cepat dan biaya yang dikeluarkan lebih murah karena terdapat efisiensi dalam hal waktu (jadwal bertemu tatap muka antara para pihak yang

${ }^{26}$ Idem.

https://www.wipo.int/amc/en/calculator/adr.jsp, diakses pada tanggal 25 Agustus 2019 pukul 19.50 WIB. 
mungkin sulit untuk ditentukan) dan biaya (transportasi dan akomodasi yang dibutuhkan). Saat ini, sistem ODR masih menggunakan situs-situs luar negeri, seperti https://odr.legalaid.com/. Secara garis besar, mekanisme Community Legal Aid SoCal yang menurut penulis dapat diterapkan untuk sistem ODR di Indonesia adalah: ${ }^{27}$

1. Membuat akun yang digunakan sebagai user pengguna ODR di Indonesia;

2. Mengajak pihak lain untuk melaksanakan alternatif penyelesaian sengketa secara online. Pada tahap ini penyedia layanan ODR mengirimkan email kepada pihak lainnya terkait permintaan penyelesaian sengketa dari pelapor;

3. Para pihak memilih alternatif penyelesaian sengketa, baik berupa negosiasi, konsiliasi, mediasi, arbitrase, arbitrase tunggal, atau penilaian ahli;

4. Para pihak yang memilih alternatif penyelesaian sengketa selain negosiasi, memilih pula fasilitator untuk membantu para pihak dalam menyelesaikan sengketa. Pada tahap ini, website dapat memperlihatkan perkiraan biaya yang akan dikeluarkan oleh pihak-pihak yang bersengketa. Perkiraan biaya dibuat seperti website SCC Institute atau WIPO AMC;

5. Para pihak dapat meng-upload dokumen-dokumen yang berkaitan dengan sengketa yang dihadapi, seperti sertifikat merek. Sertifikat merek sangat penting dalam penyelesaian sengketa merek karena konsep pendaftaran merek adalah first to file.

6. Adanya fasilitas teleconference atau video conference untuk menghubungkan para pihak secara langsung walaupun berada di tempat berbeda;

7. Dibuat perjanjian sebagai bentuk penyelesaian sengketa.

Penulis berpendapat, BAM KI dan lembaga yang menerapkan alternatif penyelesaian sengketa sebagai sarana menyelesaikan masalah antara para pihak harus terintegrasi dengan Badan Arbitrase Nasional Indonesia (BANI) dalam membuat pengembangan sistem dari situs perhitungan biaya yang dimiliki oleh WIPO AMC atau SCC Institute di atas dan menerapkan sistem ODR dalam situs tersebut, sehingga nantinya Indonesia dapat memiliki website atau aplikasi untuk menyelesaikan sengketa secara ODR secara utuh, seperti halnya WIPO AMC yang telah memiliki UDRP atau The Rules dalam menerapkan ODR dalam penyelesaian sengketa "nama domain". ${ }^{28}$ Hal yang menjadi kekurangan dari sistem online adalah bentuk arbitrase online yang paling banyak digunakan adalah arbitrase yang tidak mengikat, yaitu

\footnotetext{
${ }^{27}$ Community Legal Aid SoCal, Orange County Small Claims Online Dispute Resolution, diakses pada tanggal 2 September 2019 pukul 14.00 WIB.

${ }^{28}$ Dheka Ermelia Putri, op.cit, hlm 68.
} 
Dialogia luridica: Jurnal Hukum Bisnis dan Investasi

Vol. 11 (1): 097-113

arbitrase yang tidak menghasilkan suatu keputusan yang sama kekuatan mengikatnya seperti putusan pengadilan. Padahal dalam arbitrase konvensional, arbiter diberi kekuasaan untuk membuat putusan yang mempunyai kekuatan mengikat yang sama dengan putusan pengadilan. ${ }^{29}$ Hasil penyelesaian sengketa yang berupa putusan dari sistem ODR tersebut sangat penting bagi para pihak yang bersengketa, terutama untuk menjamin terselenggaranya keadilan, kemanfaatan, dan kepastian hukum.

\section{PENUTUP}

Alternatif penyelesaian sengketa yang diatur di Indonesia melalui Undang-Undang Nomor 30 Tahun 1999 tentang Arbitrase dan Alternatif Penyelesaian Sengketa lebih beragam dibandingkan dengan alternatif penyelelesaian sengketa yang disediakan oleh World Intellectual Property Organization (WIPO) melalui WIPO Arbitration and Mediation Center. Alternatif penyelesaian sengketa yang diatur di Indonesia dapat berupa konsultasi, mediasi, negosiasi, konsiliasi, arbitrase, dan penilaian ahli. WIPO Arbitration and Mediation Center (WIPO AMC) setidaknya memberikan 4 (empat) pilihan untuk alternatif penyelesaian sengketa, yaitu mediasi, arbitrase, expedited arbitration (arbitrase yang dipercepat), dan penilaian ahli. Hanya expedited arbitration yang tidak diatur secara eksplisit dalam UndangUndang Nomor 30 Tahun 1999 tentang Arbitrase dan Alternatif Penyelesaian Sengketa, namun dalam undang-undang tersebut terdapat ketentuan yang menyerupai expedited arbitration, yaitu adanya arbiter tunggal. Penyelesaian sengketa dengan metode di luar negeri, misalnya dengan mekanisme yang diterapkan oleh WIPO AMC, waktu dan biaya yang dikeluarkan oleh para pihak relatif murah karena dapat dilakukan melalui sistem online dan adanya keterbukaan informasi mengenai estimasi biaya yang akan dikeluarkan para pihak sebagai pertimbangan pemilihan penyelesaian sengketa. Penyelesaian sengketa yang sangat cocok untuk digunakan di masa sekarang adalah menggunakan sistem Online Dispute Resolution (ODR), sehingga akan lebih efektif dan efisien apabila semua bentuk penyelesaian sengketa tersebut di atas diakomodasi oleh sistem ODR dan para pihak dapat mempertimbangkan dari segi biaya dalam memilih metode penyelesaian sengketa. Badan Arbitrase Nasional Indonesia (BANI) sebagai lembaga yang menaungi alternatif penyelesaian sengketa di Indonesia perlu membuat regulasi dan sistem untuk menggunakan ODR dengan wadah yang dapat berupa website atau aplikasi.

\footnotetext{
${ }^{29}$ Abdul Halim Barkatullah, op.cit, hlm 372.
} 
Dialogia luridica: Jurnal Hukum Bisnis dan Investasi

Vol. 11 (1): 097-113

\section{DAFTAR PUSTAKA}

\section{Buku}

Hudiyanto, et.al, Tinjauan Umum Alternatif Penyelesaian Sengketa di Sektor Jasa Keuangan dan Online Dispute Resolution (ODR), Jakarta: Departemen Perlindungan Konsumen Otoritas Jasa Keuangan, 2017.

Suyud Margono, Penyelesaian Sengketa Bisnis Alternative Dispute Resolution (ADR), Bogor: Ghalia Indonesia, 2010.

Takdir Rahmadi, Mediasi Penyelesaian Sengketa Melalui Pendekatan Mufakat, Jakarta: Rajawali Pers, 2011.

\section{Jurnal}

Abdul Halim Barkatullah, "Penerapan Arbitrase Online Dalam Penyelesaian Sengketa Transaksi E-Commerce”, Jurnal Hukum, Vol. 17, No. 3, 2010.

Bambang Sutiyoso, "Penyelesaian Sengketa Bisnis Melalui Online Dispute Resolution dan Pemberlakukannya di Indonesia”, Mimbar Hukum, Vol. 20, No. 2, 2008.

Dheka Ermelia Putri, Penerapan Online Dispute Resolution (ODR) Dalam Penyelesaian Sengketa Nama Domain Internasional, Fakultas Hukum Universitas Lampung, 2018.

Henry Donald Lbn Toruan, "Penyelesaian Sengketa Intelektual Melalui Acara Cepat”, Jurnal Penelitian Hukum De Jure, Vol. 17, No. 1, 2017.

Idris Talib, "Bentuk Putusan Penyelesaian Sengketa Berdasarkan Mediasi”, Lex et Societatis, Vol.I, No.1, 2013.

Marwah M. Diah, "Prinsip dan Bentuk-Bentuk Alternatif Penyelesaian Sengketa di Luar Pengadilan”, Hukum dan Dinamika Masyarakat, Vol. 5, No. 2, 2008.

Nevey Varida Ariani, “Alternatif Penyelesaian Sengketa Bisnis di Luar Pengadilan”, Jurnal Rechtsvinding, Vol. 1 No. 2, 2012.

Rahmi Yuniarti, "Efisiensi Pemilihan Alternatif Penyelesaian Sengketa Dalam Penyelesaian Sengketa Waralaba", Fiat Justitia Journal of Law, Vol. 10, Issue 3, 2016.

Sedjana, "Efektivitas dan Efisiensi Penyelesaian Sengketa Kekayaan Intelektual Melalui Arbitase dan Mediasi Berdasarkan Undang-Undang Nomor 30 Tahun 1999”, AJUDIKASI: Jurnal Ilmu Hukum, Vol. 2, No. 1, 2018. 


\section{Peraturan Perundang-undangan}

Undang-Undang Nomor 20 Tahun 2016 tentang Merek dan Indikasi Geografis.

Undang-Undang Nomor 30 Tahun 1999 tentang Arbitase dan Alternatif Penyelesaian Sengketa.

Peraturan Mahkamah Agung Republik Indonesia Nomor 1 Tahun 2016 tentang Prosedur Mediasi di Luar Pengadilan.

\section{Pranalar Luar}

Arbitration Institute of the Stockholm Chamber of Commerce, diakses melalui https://sccinstitute.com/our-services/calculator/ pada tanggal 25 Agustus 2019 pukul 20.00 WIB.

Claus Matthes, Recent Developments in WIPO Administered IP Services, Munich: World Intellectual Property Organization (WIPO), 2016.

Community Legal Aid SoCal, Orange County Small Claims Online Dispute Resolution, diakses pada tanggal 2 September 2019 pukul 14.00 WIB.

Guidelines Mediasi untuk Direktorat Jenderal Hak Kekayaan Intelektual Kementerian Hukum dan HAM RI.

Madjedi Hasan, "Hal-Hal yang Perlu Dipertimbangkan Sebelum Menandatangani Kesepakatan Berarbitrase, Indonesian Arbitration", Quarterly Newsletter, No. 11 Tahun 2010.

Matthew Bryan, “Resolving IP Disputes outside the Courts through WIPO ADR: WIPO's Arbitration and Mediation Center", Roving Seminar on WIPO Services and Initiatives, 2015.

https://bppk.kemenkeu.go.id/id/publikasi/artikel/147-artikel-anggaran-danperbendaharaan/9925-penyelesaian-sengketa-dalam-pengadaan-barangjasa-pemerintahmelalui-alternative-dispute-resolution, diakses pada tanggal 20 Agustus 2019, pukul 17.00 WIB. 